\title{
Maxillofacial Fractures due to Falls: does Fall Modality Determine the Pattern of Injury?
}

\author{
Fabio Roccia ${ }^{1}$, Paolo Boffano ${ }^{1}$, Francesca A. Bianchi ${ }^{1}$, Emanuele Zavattero ${ }^{1}$ \\ ${ }^{1}$ Surgical Science Department, San Giovanni Battista Hospital, University of Turin, Turin, Italy.
}

\author{
Corresponding Author: \\ Fabio Roccia \\ Surgical Science Department, San Giovanni Battista Hospital \\ University of Turin \\ 10133, Corso A.M. Dogliotti 14, Turin \\ Italy \\ Phone: +390116335125 \\ E-mail: fabio.roccia@poste.it
}

\begin{abstract}
Objectives: In several epidemiological studies of maxillofacial trauma, falls were one of the most frequent causes of facial injury. The aim of this study is to analyse the patterns of fall-related maxillofacial injuries based on the height of the fall.

Material and Methods: Using a systematic computer-assisted database of patients hospitalised with maxillofacial fractures, only those with fall-related injuries were considered. The falls were divided into four groups: falls from slipping, tripping or stumbling (STSF), loss of consciousness (LOCF), stairs (SAF), and height (HF). Data on the age, gender, fracture site, Facial Injury Severity Scale (FISS), facial lacerations, associated lesions, type of treatment, and length of hospital stay were also analysed.

Results: This study included 557 patients (338 males, 219 females; average age 51.5 years [range 4 - 99 years]). In the over 60 age group, females were more prevalent in STSF than males. According to aetiology, STSF was the most frequent cause of maxillofacial fractures (315 patients; 56.5\%) followed by LOCF (157; 28.2\%), HF (55; 9.9\%), and SAF (30; 5.4\%). The middle third of the face was affected most frequently. After LOCF, however, the inferior third was prevalently involved. The majority of associated fractures, as well as the most severe injuries and greatest rate of facial lacerations, occurred secondary to HF.
\end{abstract}

Conclusions: This study showed that fracture severity and site are influenced not only by patient age, but also by the nature of the fall.

Keywords: accidental falls; etiology; facial injuries; maxillofacial injuries.

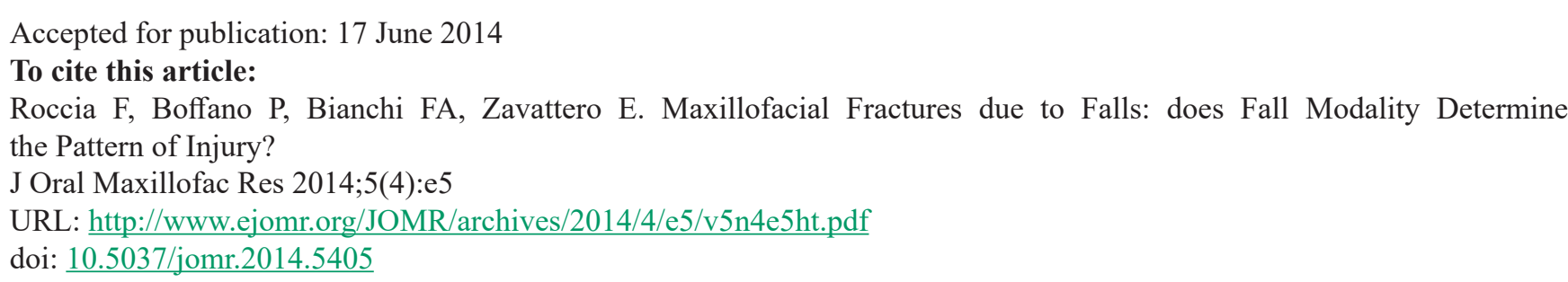




\section{INTRODUCTION}

Falls are one of the most important causes of maxillofacial injuries, especially in developed countries, and are usually discussed together with motor-vehicle accidents, sport, violence, and work [1-7].

Several articles studied and considered falls alone [8-10]. Other articles examined falls according to patient age; i.e., falls in the paediatric population [11] or in old patients [12], according to height [13], or according to the cause of the falls, such as slipping and tripping [14], loss of consciousness [15], epilepsy [16-18], and bicycle accidents [19-21].

The aim of the present study is to assess falls according to their height and consequences in the maxillofacial region.

\section{MATERIAL AND METHODS}

This study involved a systematic computer-assisted database that has continuously recorded patients hospitalised with maxillofacial fractures at the Division of Maxillofacial surgery, San Giovanni Battista Hospital, Turin, Italy, since January 2001, with a software update in 2009 [22]. Only patients who presented with a "fall" in the database field for "cause of injury" over the period from 1 January 2001 to 31 December 2013 were considered for this study.

The field "mechanism of injury" classified falls in four groups: from slipping, tripping or stumbling (STSF), from loss of consciousness (LOCF), from stairs (SAF), and from heights (HF). Falls from bicycles were excluded from this study.

The group STSF was characterised by an accidental fall that had occurred on a level surface and resulted from a loss of control while walking, running, or playing, and could have happened indoors or out. The second group were LOCF that had occurred on a level surface and occurred either outdoors or indoor due to several causes, such as lipothymia, syncope, psychoactive drug abuse, alcohol/drugs addiction, and neurological disorders. The third group included SAF that resulted from a loss of equilibrium while going down stairs. The fourth group included HF, and were sub-classified according to height into low $(<3 \mathrm{~m})$ and high falls $(>3 \mathrm{~m})$. They had several causes, such as accidents in the workplace and suicide attempts.

The following data were considered for each patient: age, gender, site and severity of facial fracture Facial Injury Severity Scale (FISS) [23], facial lacerations according to the MCFONTZL classification system [24] as modified by Roccia et al. [25], associated injuries, type of treatment, and hospital stay.

\section{Statistical analysis}

Statistical analysis was used to search for associations among multiple variables, including age, gender, FISS, and fracture location. Data were expressed as mean and standard deviation (M [SD]). Statistical significance was determined using the $\chi^{2}$ or Fisher's exact test if the sample sizes were too small. The significance level was set at $\mathrm{P}<0.05$.

\section{RESULTS}

In total, 557 patients (338 males and 219 females [ratio 1.5:1], mean age 51.5 years [range 4 - 99 years]) were admitted to our division for maxillofacial fractures following falls.

As reported in Figure 1, falls were less frequent in people younger than 20 years, and had a higher incidence in the decade from 70 and 79 years, followed by the sixth and the third decades. Moreover, an inversion of the male-to-female ratio was observed in the first decade and above 80 years.

Subdividing the patients into three groups, children ( $<16$ years), adults, and the elderly ( $>60$ years) (Figure 2), we observe an inversion in the male-tofemale ratio in the $>60$ years group, particularly for STSF fractures.

In terms of fall aetiology, facial fractures followed in 315 (56.5\%) STSF, 157 (28.2\%) LOCF, 55 (9.9\%) HF, and $30(5.4 \%)$ SAF patients. The falls occurred indoors in 327 patients and outdoors in 230.

In the STSF group, there were 210 indoor falls, mainly at home, versus 105 outdoors falls, mainly walking. The LOCF falls (85 indoor and 72 outdoor) resulted from lipothymia (83 patients), neurological disorders (34 patients, including 19 cases of epilepsy), alcohol abuse (22 patients), psychoactive drug abuse (9 cases), syncope (7 patients), and vertiginous syndrome (2 cases). The HF falls (53 outdoors, 2 indoors) occurred from heights $<3$ metres in 19 patients and $>3$ metres in 36 patients. The first subgroup included 6 falls from rung ladders, while the second subgroup included 11 falls from scaffolding, 8 from balconies, and 4 from suicidal attempts. Of the $55 \mathrm{HF}$ falls, 24 were work-related. Of the $30 \mathrm{SAF}$ falls, 21 occurred on a home staircase.

Figure 3 shows that among the 769 fractures of the facial skeleton, in the STSF, HF, and SAF groups the middle third of the face was the most involved region and the orbito-zygomatic-maxillary (OZM) complex was the most frequent fracture, together with the mandibular condyle (Table 1). 


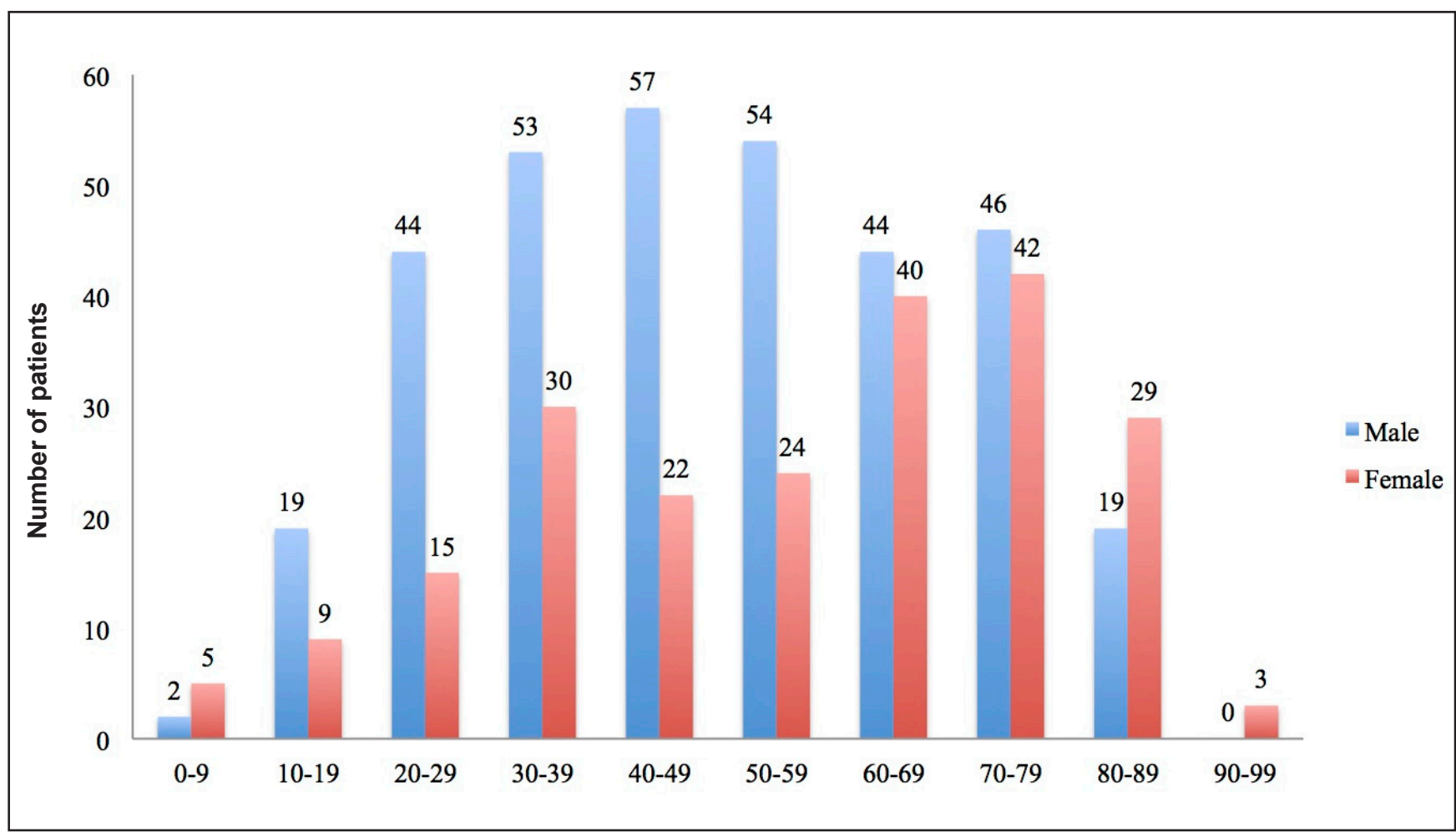

Figure 1. Patients' distribution according to age and gender.

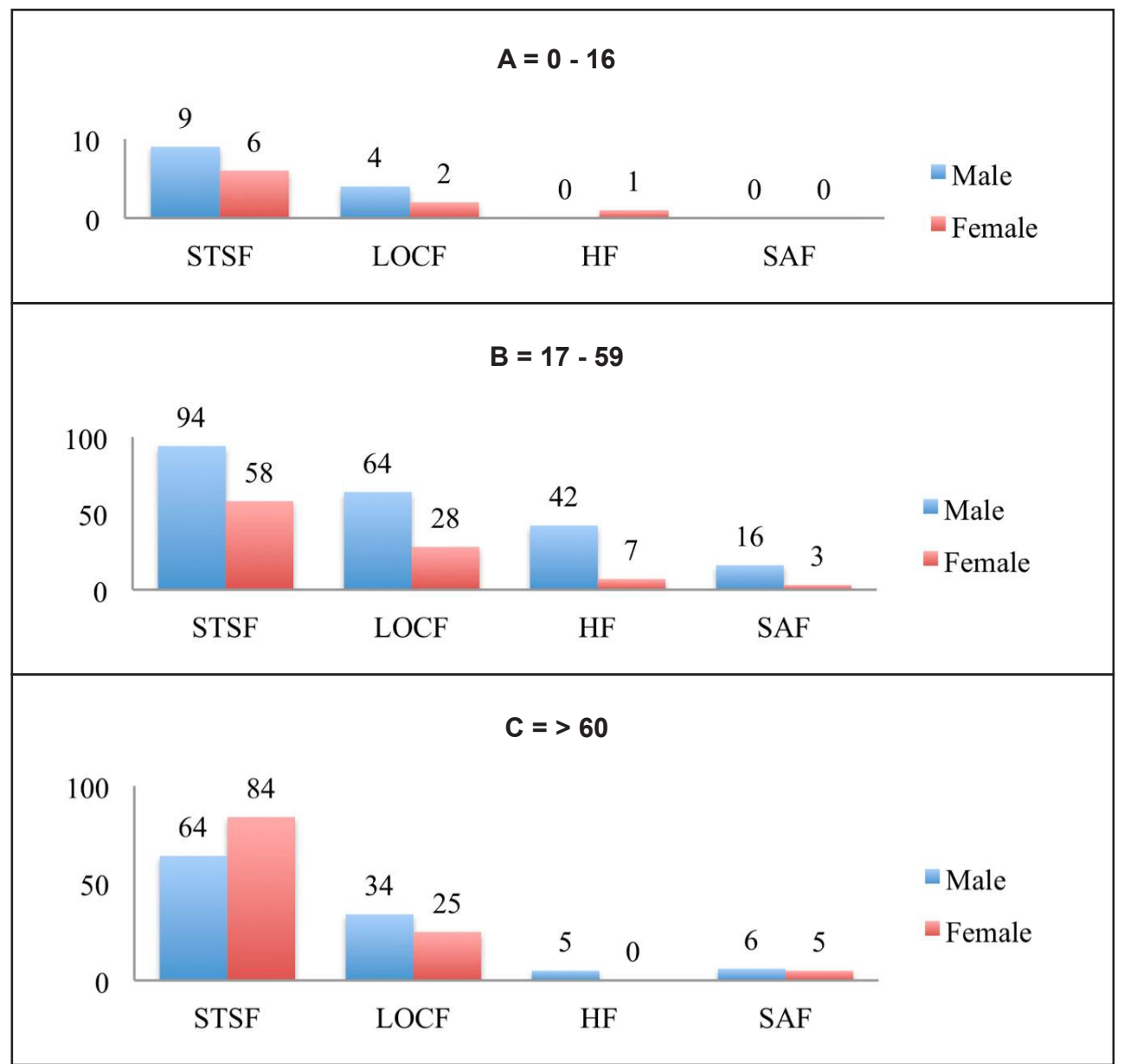

Figure 2. Comparison between causes of fall and patients' age groups: $A=0-16 ; B=17-59 ; C=>60$.

$\mathrm{STSF}=$ falls from slipping, tripping or stumbling; LOCF $=$ falls from loss of consciousness; SAF $=$ falls from stairs; HF $=$ falls from heights. 


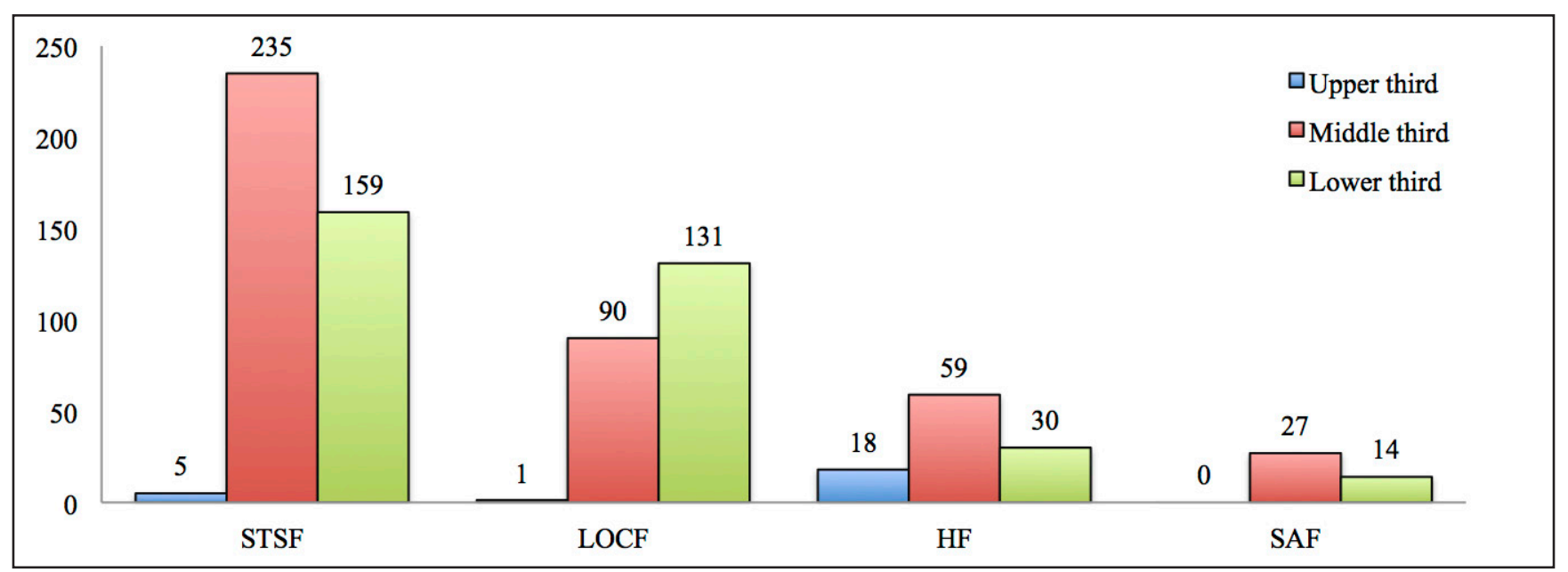

Figure 3. Comparison of causes of falls and site of patients' maxillofacial injuries.

$\mathrm{STSF}=$ falls from slipping, tripping or stumbling; LOCF $=$ falls from loss of consciousness; $\mathrm{SAF}=$ falls from stairs; HF $=$ falls from heights.

Table 1. Comparison of causes of falls and maxillofacial fractures

\begin{tabular}{|c|c|c|c|c|c|c|c|c|c|c|c|c|}
\hline & & & STSF & $\%$ & LOCF & $\%$ & HF & $\%$ & SAF & $\%$ & FALLS & $\%$ \\
\hline \multirow{3}{*}{$\begin{array}{l}\text { Upper } \\
\text { third }\end{array}$} & \multirow{3}{*}{$\begin{array}{l}\text { Frontal } \\
\text { sinus }\end{array}$} & Anterior wall & 4 & \multirow{3}{*}{1.3} & 4 & \multirow{3}{*}{0.5} & 4 & \multirow{3}{*}{16.8} & 0 & \multirow{3}{*}{0} & 9 & \multirow{3}{*}{3.1} \\
\hline & & Anterior and posterior & 1 & & 0 & & 13 & & 0 & & 14 & \\
\hline & & Posterior wall & 0 & & 0 & & 1 & & 0 & & 1 & \\
\hline \multirow{10}{*}{$\begin{array}{l}\text { Middle } \\
\text { third }\end{array}$} & \multicolumn{2}{|c|}{ Maxillo-zygomatic-orbital complex } & 95 & \multirow{10}{*}{58.9} & 42 & \multirow{10}{*}{40.5} & 17 & \multirow{10}{*}{55.2} & 15 & \multirow{10}{*}{65.9} & 169 & \multirow{10}{*}{53.5} \\
\hline & \multirow{3}{*}{ Orbit } & Floor & 80 & & 16 & & 7 & & 3 & & 106 & \\
\hline & & Medial wall & 15 & & 4 & & 1 & & 2 & & 22 & \\
\hline & & Roof & 5 & & 0 & & 5 & & 0 & & 10 & \\
\hline & \multicolumn{2}{|c|}{ Zygomatic arch } & 17 & & 5 & & 0 & & 2 & & 24 & \\
\hline & \multicolumn{2}{|l|}{ Nose } & 16 & & 12 & & 9 & & 2 & & 39 & \\
\hline & \multicolumn{2}{|l|}{ Le Fort } & 4 & & 8 & & 11 & & 2 & & 25 & \\
\hline & \multicolumn{2}{|l|}{ NOE } & 1 & & 0 & & 4 & & 0 & & 5 & \\
\hline & \multicolumn{2}{|c|}{ Dento-alveolar } & 2 & & 2 & & 1 & & 1 & & 6 & \\
\hline & \multicolumn{2}{|c|}{ Palatal bone } & 0 & & 1 & & 4 & & 0 & & 5 & \\
\hline \multirow{7}{*}{$\begin{array}{l}\text { Lower } \\
\text { third }\end{array}$} & \multicolumn{2}{|l|}{ Condyle } & 75 & \multirow{7}{*}{39.8} & 71 & \multirow{7}{*}{59} & 11 & \multirow{7}{*}{28} & 5 & \multirow{7}{*}{34.1} & 162 & \\
\hline & \multicolumn{2}{|l|}{ Angle } & 29 & & 15 & & 2 & & 3 & & 49 & \\
\hline & \multicolumn{2}{|l|}{ Body } & 21 & & 10 & & 4 & & 0 & & 35 & \\
\hline & \multicolumn{2}{|c|}{ Parasymphysis } & 16 & & 20 & & 9 & & 5 & & 50 & 43.4 \\
\hline & \multicolumn{2}{|c|}{ Symphysis } & 11 & & 12 & & 4 & & 1 & & 28 & \\
\hline & \multicolumn{2}{|c|}{ Coronoid } & 4 & & 0 & & 0 & & 0 & & 4 & \\
\hline & Dento-al & eolar & 3 & & 3 & & 0 & & 0 & & 6 & \\
\hline Total & & & 399 & & 222 & & 107 & & 41 & & 769 & 100 \\
\hline
\end{tabular}

$\mathrm{STSF}=$ falls from slipping, tripping or stumbling; LOCF $=$ falls from loss of consciousness; $\mathrm{SAF}=$ falls from stairs; HF $=$ falls from heights.

In comparison, in the LOCF falls, the lower third of the face had the highest percentage of maxillofacial injuries $(56 \%)$ and the condyle was the most common site of fracture. The percentage tended to decrease with increasing height, to $28 \%$ in the HF falls.

The HF group had the highest FISS score of 4.54 (4.21) (6.05 [4.51] for falls $>3 \mathrm{~m}$ and 1.68 [1.2] for falls $<3 \mathrm{~m}$ ), whereas the FISS was $1.97(1.53)$ in LOCF, 1.7 (1.53) in SAF, and 1.57 (0.91) in STSF. Overall, 207 patients $(37.2 \%)$ had 232 facial lacerations. Half of these were localised to the lower third of the face, mainly in the chin region. As shown in Figure 4, most facial lacerations were located between the upper eyelids, or on the forehead, nose, upper and lower lips, and chin. If we consider the facial lacerations according to the type of fall, a greater rate of lacerations per patient was observed 
in HF falls (Figure 5).

In total, 114 patients $(20.5 \%)$ presented with associated injuries, which were mainly orthopaedic (especially involving the limbs), followed by neurosurgical and thoracic (particularly the costal bones) (Table 2). Overall, $80 \%$ of the patients with HF

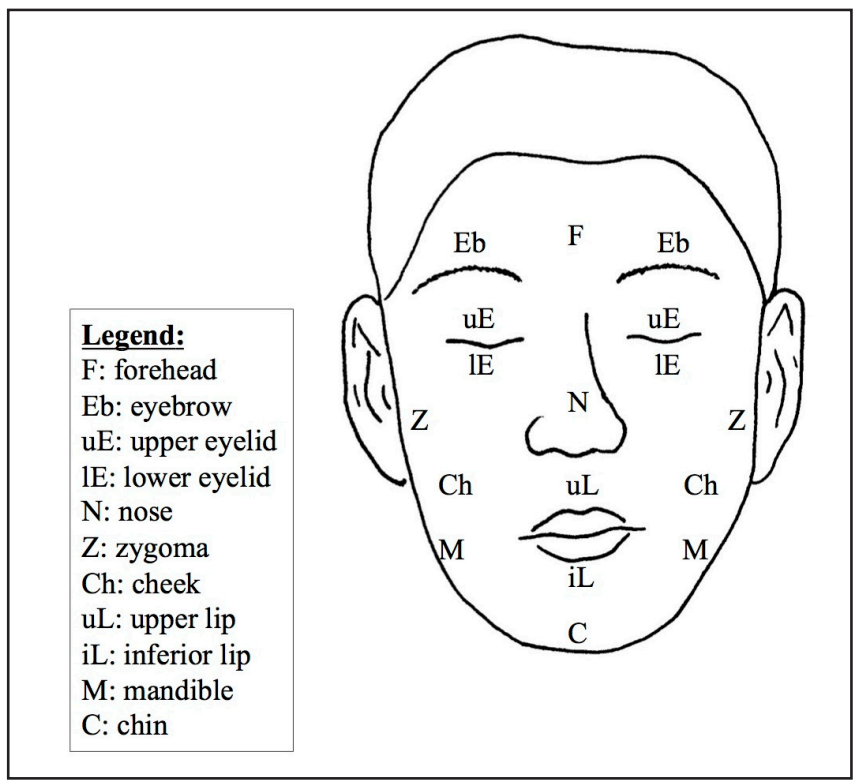

Figure 4. Modified MCFONTZL classification of facial lacerations [24]. facial fractures had associated injuries, versus $30 \%$ for SAF, $14 \%$ for STSF, and $10 \%$ for LOCF.

Of the 557 patients admitted, the maxillofacial fractures required open reduction in 389 cases $(69.9 \%)$ and closed reduction in 91 cases $(16.3 \%)$, while 77 patients did not require surgical intervention, including $46 \mathrm{STSF}, 27 \mathrm{LOCF}, 3 \mathrm{SF}$, and $1 \mathrm{HF}$. Of the 77 non-operated patients, 57 were older than 60 years (74\%), 19 were adults, and just one was under 16 years.

The hospital stay averaged 10.5 (9.27) days in HF, 4.8 (4) in LOCF, 4 (3) in STSF and 4.63 (3.36) in SAF.

Table 2. Number of concomitant injuries depending on causes of falls

\begin{tabular}{l|c|c|c|c|c}
\hline & STSF & LOCF & HF & SAF & FALLS \\
\hline Orthopaedic & 27 & 9 & 30 & 8 & 74 \\
\hline Encephalic & 6 & 3 & 14 & 2 & 25 \\
\hline Thoracic & 4 & 1 & 10 & 2 & 17 \\
\hline Ocular & 8 & 2 & 4 & 1 & 15 \\
\hline Abdominal & 0 & 0 & 3 & 0 & 3 \\
\hline \multicolumn{1}{c}{ Total } & 45 & 15 & 61 & 13 & 134 \\
\hline
\end{tabular}

$\mathrm{STSF}=$ falls from slipping, tripping or stumbling; $\mathrm{LOCF}=$ falls from loss of consciousness; $\mathrm{SAF}=$ falls from stairs; $\mathrm{HF}=$ falls from heights.

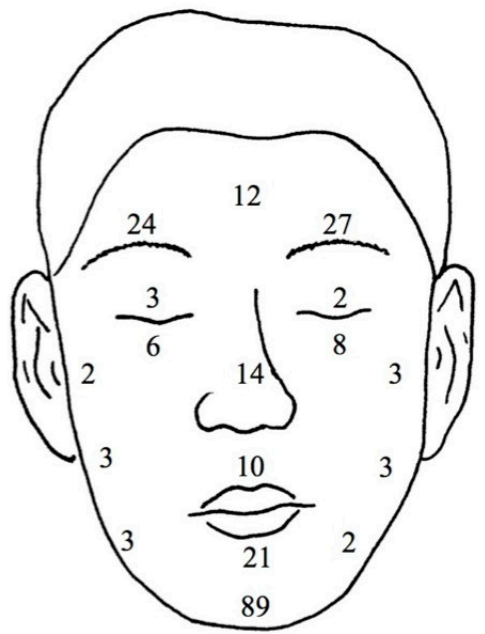

Total facial lacerations: 232

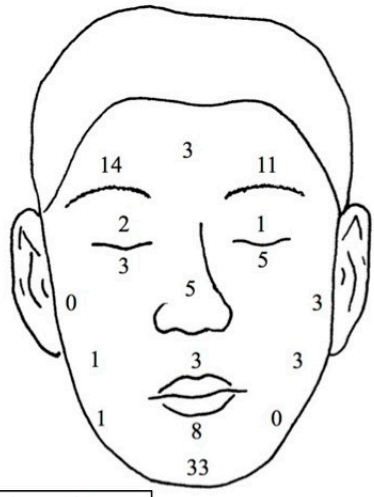

STSF: 93/ 315

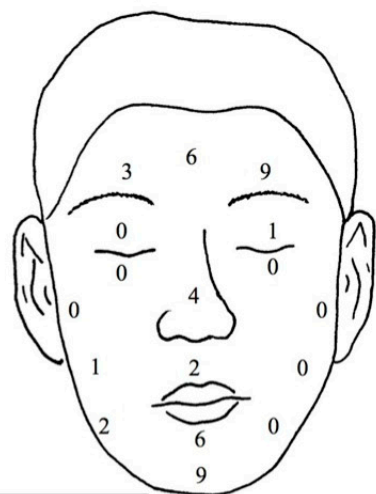

HF: 43/ 55

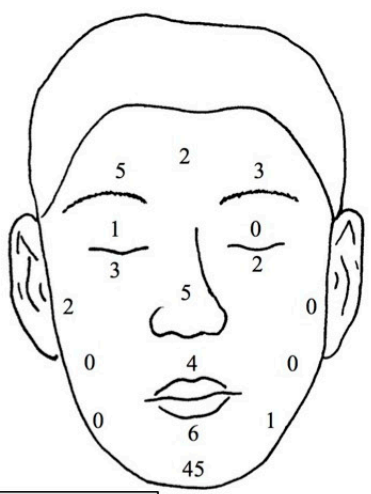

LOCF: 79/ 157

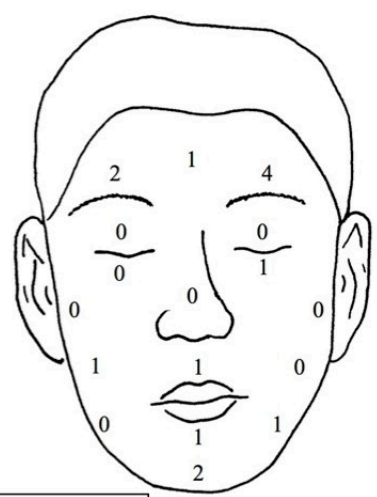

SAF: $14 / 30$

Figure 5. Distribution of facial lacerations according to types of fall. STSF = falls from slipping, tripping or stumbling; LOCF $=$ falls from loss of consciousness; $\mathrm{SAF}=$ falls from stairs; $\mathrm{HF}=$ falls from heights . 
Overall, a significant association was observed between older age and female gender $(\mathrm{P}<0.005$; odds ratio [OR] 1.83; 95\% confidence interval [CI] 1.29 2.59). In the STSF group, a significant association was observed between age and female $(\mathrm{P}<0.005$; OR 2.11; 95\% CI 1.34 - 3.32). In the LOCF group, no association was found between age and gender, whereas adequate statistical analysis could not be done for the HF and SAF groups because of the small numbers of females.

Regarding fracture site, significant associations were observed between STSF and fractures of the middle third ( $\mathrm{P}<0.0000005$; OR 3.01; 95\% CI 2.3 - 3.94), between $\mathrm{HF}$ and fractures of the middle third ( $\mathrm{P}<00005$; OR 2.31; 95\% CI 1.54 - 3.47), and between SAF and fractures of the middle third ( $\mathrm{P}<0005$; OR 3.66; 95\% CI 1.90 - 7.23).

\section{DISCUSSION}

Maxillofacial fractures following falls are relatively frequent. They are the main cause of injury in our division, as reported in recent articles [26,27].

The World Health Organisation [28] defined falls as "inadvertently coming to rest on the ground, floor or other level, excluding intentional change in position to rest in furniture, wall or other objects". Falls occur as a result of a complex interaction of risk factors. The main risk factors reflect the multitude of health determinants that directly or indirectly affect well-being. These are categorised into biological (e.g. age, gender, race, chronic illness), behavioural (e.g. multiple medications use, excess alcohol intake), environmental (e.g. slippery floors and stairs, loose rugs), and socioeconomic (e.g. low income and education levels, inadequate housing) factors [28].

Unlike many previous studies of falls incorporating specific height inclusion criteria, we analysed falls from all heights and different patterns of facial trauma. The height of the fall determines the kinetic energy transmitted to the victim. This kinetic energy, along with the landing position, location of contact, and impact surface determines the injury pattern and severity $[\underline{29}, \underline{30}]$.

Falls on level surfaces ( $85 \%$ of patients) were the most frequent cause in our study population. In more than half of the cases, the falls followed slipping, tripping, or stumbling. In this category of falls, a person falls down immediately forward, backward or laterally, when walking or running, and often tries to use the hands for protection.

The STSF group consisted of almost equal numbers of adults $(\mathrm{n}=152)$ and elderly $(\mathrm{n}=148)$. In agreement with several articles [ㅇ, 10, 31-33], we observed a majority of females in the group over 60 , which could be partially explained by the longer life expectancy of females versus males. Furthermore, geriatric and orthopaedic studies showed a relationship between falls and osteoporosis, so that older women are more likely to present with fractures associated with osteoporosis [34-36].

Finally, traumatic events in the elderly are often related to intrinsic factors, such as neuromuscular and cognitive impairment, disturbances of balance and gait, environmental hazards, drugs (psychotropic, polypharmacy), cardiovascular risk factors, feet and footwear, medical problems, depression, and cerebrovascular lesions $[\underline{12}, \underline{37}]$.

In the STSF patients, fractures of the middle third (especially OZM fractures) were predominant, as in the other groups, with the exception of LOCF patients. The injury severity was lower than in the other groups, probably because in this type of fall the patient instinctively tries to stop the fall, thereby minimising the impact with the ground [요, 14, $\underline{31}$. This explains the threefold greater frequency of orthopaedic "protection" injuries (especially to the upper limbs) in comparison with the LOCF group.

In contrast, LOCF is not associated with a protection mechanism because the patient falls down as an "inert" body. The patient with epilepsy has an increased risk of accidental injuries due to loss of the muscle tone and self-protective reflexes that minimise trauma during a fall $[\underline{16}, \underline{17}]$.

In our study population, LOCF involved mainly males of all ages. In more than half of the patients, it was caused by lipothymia, often following hypotension, or fever following influenza, with amnesia for the traumatic event. In agreement with Haug et al. [38] and Hung et al. [15], the lower third was the most frequently involved facial region in this group of patients.

As Halazonetis [이 ] postulated, we believe that loss of consciousness prevents the muscles of the body from contracting at the moment of impact with the ground. Consequently, the teeth are not clenched at the moment of impact, leaving the condyle unprotected. The fact that most lacerations were observed on the chin following LOCF (Figure 5) seems to confirm the greater frequency of direct injuries to the anterior region of the mandible, with the transmission of forces to the condyle, as found in a previous study of ours [25].

Finally, the severity of facial fractures in LOCF, with no possibility of performing protective actions to attenuate the impact of the face with the ground, was demonstrated by the high FISS score, similar to that 
for $\mathrm{HF}<3 \mathrm{~m}$, higher than for STSF and SAF.

We expected that falls from heights, such as from ladders, would produce more severe maxillofacial fractures than falls on a level surface. On the contrary, the maxillofacial fractures in the 30 SAF patients involved mainly the middle third and they had an FISS score slightly greater than that of STSF, as also reported by Yamamoto et al. [10]. The same protection reflex as in STSF likely occurs in SAF to attenuate the severity of injury.

A progressive decrease in maxillofacial fractures of the lower third was observed as the height of the fall increased, with $59 \%$ in LOCF, $40 \%$ in STSF, $34 \%$ in $\mathrm{SAF}$, and $28 \%$ in $\mathrm{HF}$.

$\mathrm{HF}$ is an important cause of maxillofacial trauma, frequently associated with severe injuries to multiple organs. In agreement with Salonen et al. [13] and Yamamoto et al. [10], almost all 55 patients with maxillofacial fractures following HF were males, between 17 and 59 years. Yamamoto et al. [10] believe that "these findings are partly because men are socially active and therefore more frequently encounter accidents". This statement was confirmed in our study, in which almost half of the HF occurred in the workplace. Maxillofacial fractures of the middle third were the most numerous in this group of patients. However, we identified a relatively high percentage of craniomaxillofacial fractures involving the upper third, with frequent involvement of both walls of the frontal sinus. Furthermore, the fractures of the frontal sinus occurred mainly in patients who had fallen from heights $>3 \mathrm{~m}$ (17 of 36 versus 2 of 19 patients). These findings support the hypothesis of Atanasijevic et al. [40], who said that "the frequency of head injuries is the highest in falls from heights below $7 \mathrm{~m}$ ". Likewise Dickinson et al. [41] observed that "accidental fallers from height are more likely to fall headfirst", with a consequent lower percentage of maxillofacial fractures of the lower third. The relatively high incidence of associated neurosurgical lesions in this group seems to confirm such hypotheses.
Finally, the severity and complexity of maxillofacial fractures determined by HF was demonstrated by the high FISS score and high percentage of treated patients (54 of 55), with a consequent longer hospital stay.

\section{CONCLUSIONS}

Falls and associated injuries are a priority issue for the national health systems in Europe and elsewhere, especially considering the rapidly increasing life expectancy.

This study found that maxillofacial injuries associated with falls are influenced not only by age, but also by the nature of the fall. We observed that falls on a level floor (especially from slipping, tripping or stumbling) are the most important cause of facial fractures, with females being the most involved in the elderly population. Furthermore, in falls on a level floor, the injuries are more severe when patients fall without an efficacious protection reflex to attenuate the impact with the ground. We found that in injuries from loss of consciousness, despite the general prevalence of maxillofacial fractures of the middle third in falls, fractures of the lower third were more frequent, and that their percentage decreases as the height of the fall increases. Finally, the most severe maxillofacial and associated injuries occurred following the falls from heights, especially $>3 \mathrm{~m}$.

In summary, we believe that the mode of falling must be considered as a separate aetiological factor in maxillofacial trauma, so as to prevent and manage maxillofacial injuries following falls and increase the accuracy of investigations.

\section{ACKNOWLEDGMENTS AND DISCLOSURE STATEMENTS}

The authors report no conflicts of interest related to this study.

\section{REFERENCES}

1. Gassner R, Tuli T, Hächl O, Rudisch A, Ulmer H. Cranio-maxillofacial trauma: a 10 year review of 9,543 cases with 21,067 injuries. J Craniomaxillofac Surg. 2003 Feb;31(1):51-61. [Medline: 12553928] [doi: 10.1016/S1010-5182(02)00168-3]

2. Erol B, Tanrikulu R, Görgün B. Maxillofacial fractures. Analysis of demographic distribution and treatment in 2901 patients (25-year experience). J Craniomaxillofac Surg. 2004 Oct;32(5):308-13. [Medline: 15458673] [doi: 10.1016/i.jems.2004.04.006]

3. Kontio R, Suuronen R, Ponkkonen H, Lindqvist C, Laine P. Have the causes of maxillofacial fractures changed over the last 16 years in Finland? An epidemiological study of 725 fractures. Dent Traumatol. 2005 Feb;21(1):14-9. [Medline: 15660750$]$ [doi: $\underline{10.1111 / j .1600-9657.2004 .00262 . x}$ ] 
4. Roden KS, Tong W, Surrusco M, Shockley WW, Van Aalst JA, Hultman CS. Changing characteristics of facial fractures treated at a regional, level 1 trauma center, from 2005 to 2010: an assessment of patient demographics, referral patterns, etiology of injury, anatomic location, and clinical outcomes. Ann Plast Surg. 2012 May;68(5):461-6. [Medline: 22531401] [doi: 10.1097/SAP.0b013e31823b69dd]

5. Smith H, Peek-Asa C, Nesheim D, Nish A, Normandin P, Sahr S. Etiology, diagnosis, and characteristics of facial fracture at a midwestern level I trauma center. J Trauma Nurs. 2012 Jan-Mar;19(1):57-65. [Medline: 22415509] [doi: 10.1097/JTN.0b013e31823a4c0e]

6. van den Bergh B, Karagozoglu KH, Heymans MW, Forouzanfar T. Aetiology and incidence of maxillofacial trauma in Amsterdam: a retrospective analysis of 579 patients. J Craniomaxillofac Surg. 2012 Sep;40(6):e165-9. Epub 2011 Sep 14. [Medline: 21917471] [doi: 10.1016/i.jcms.2011.08.006]

7. Walker TW, Byrne S, Donnellan J, McArdle N, Kerin MJ, McCann PJ. West of Ireland facial injury study. Part 1. Br J Oral Maxillofac Surg. 2012 Oct;50(7):631-5. Epub 2011 Dec 20. [Medline: 22192609] [doi: 10.1016/j.bjoms.2011.09.025]

8. Iida S, Hassfeld S, Reuther T, Schweigert HG, Haag C, Klein J, Mühling J. Maxillofacial fractures resulting from falls. J Craniomaxillofac Surg. 2003 Oct;31(5):278-83. [Medline: 14563327] [doi: 10.1016/S1010-5182(03)00069-6]

9. Salonen EM, Koivikko MP, Koskinen SK. Acute facial trauma in falling accidents: MDCT analysis of 500 patients. Emerg Radiol. 2008 Jul;15(4):241-7. Epub 2008 May 15. [Medline: 18481126] [doi: 10.1007/s10140-008-0717-2]

10. Yamamoto K, Kuraki M, Kurihara M, Matsusue Y, Murakami K, Horita S, Sugiura T, Kirita T. Maxillofacial fractures resulting from falls. J Oral Maxillofac Surg. 2010 Jul;68(7):1602-7. Epub 2010 Apr 22. [Medline: 20417013] [doi: 10.1016/i.joms.2009.09.029]

11. Chang LT, Tsai MC. Craniofacial injuries from slip, trip, and fall accidents of children. J Trauma. 2007 Jul;63(1):70-4. [Medline: 17622871] [doi: 10.1097/01.ta.0000219142.15584.b8]

12. Wade CV, Hoffman GR, Brennan PA. Falls in elderly people that result in facial injuries. Br J Oral Maxillofac Surg. 2004 Apr;42(2):138-41. [Medline: 15013546] [doi: 10.1016/S0266-4356(03)00256-0]

13. Salonen EM, Koivikko MP, Koskinen SK. Multidetector computed tomography imaging of facial trauma in accidental falls from heights. Acta Radiol. 2007 May;48(4):449-55. [Medline: 17453528] [doi: 10.1080/02841850701199959]

14. Zandi M, Saleh M, Seyed Hoseini SR. Are facial injuries caused by stumbling different from other kinds of fall accidents? J Craniofac Surg. 2011 Nov;22(6):2388-92. [Medline: 22134289] [doi: 10.1097/SCS.0b013e318231fca3]

15. Hung YC, Montazem A, Costello MA. The correlation between mandible fractures and loss of consciousness. J Oral Maxillofac Surg. 2004 Aug;62(8):938-42. [Medline: 15278857] [doi: 10.1016/j.joms.2004.01.018]

16. Kulahci Y, Sever C, Uygur F, Senol MG, Cayci T. Mandible fractures during epileptic seizure: two case reports. Eur J Plast Surg 2009 May; 32: 253-5. [doi: 10.1007/s00238-009-0337-4]

17. Costa AL, Yasuda CL, França MC Jr, Morita ME, Cendes F. Refractory epilepsy is highly associated with severe dentoalveolar and maxillofacial injuries. Epileptic Disord. 2011 Mar;13(1):61-4. [Medline: 21393092] [doi: 10.1684/epd.2011.0401]

18. Nonato ER, Borges MA. Oral and maxillofacial trauma in patients with epilepsy: prospective study based on an outpatient population. Arq Neuropsiquiatr. 2011 Jun;69(3):491-5. [Medline: 21755128] [doi: 10.1590/S0004-282X2011000400016]

19. Yamamoto K, Matsusue Y, Horita S, Murakami K, Sugiura T, Kirita T. Maxillofacial fractures sustained in bicycle accidents. J Oral Maxillofac Surg. 2011 Jun;69(6):e155-60. Epub 2011 Apr 15. [Medline: 21496994] [doi: 10.1016/j.joms.2010.12.028]

20. Júnior SM, Santos SE, Kluppel LE, Asprino L, Moreira RW, de Moraes M. A comparison of motorcycle and bicycle accidents in oral and maxillofacial trauma. J Oral Maxillofac Surg. 2012 Mar;70(3):577-83. Epub 2011 Jun 12. [Medline: 21665346] [doi: 10.1016/j.joms.2011.03.035]

21. Boffano P, Roccia F, Gallesio C, Karagozoglu KH, Forouzanfar T. Bicycle-related maxillofacial injuries: a double-center study. Oral Surg Oral Med Oral Pathol Oral Radiol. 2013 Sep;116(3):275-80. Epub 2013 May 7. [Medline: 23663988] [doi: 10.1016/j.0000.2013.03.004]

22. Roccia F, Caldarelli C, Spada MC, Brucoli M, Beatrice F, Ruffino S, Benech A, Ramieri G, Berrone S. Development of a regional database for studying epidemiology of maxillofacial trauma. J Craniofac Surg. 2010 Jul;21(4):1045-50. [Medline: 20613554] [doi: 10.1097/SCS.0b013e3181e62c94]

23. Bagheri SC, Dierks EJ, Kademani D, Holmgren E, Bell RB, Hommer L, Potter BE. Application of a facial injury severity scale in craniomaxillofacial trauma. J Oral Maxillofac Surg. 2006 Mar;64(3):408-14. [Medline: 16487802] [doi: 10.1016/i.joms.2005.11.013]

24. Lee RH, Gamble WB, Robertson B, Manson PN. The MCFONTZL classification system for soft-tissue injuries to the face. Plast Reconstr Surg. 1999 Apr;103(4):1150-7. [Medline: 10088500] [doi: 10.1097/00006534-199904010-00008]

25. Roccia F, Bianchi FA, Zavattero E, Baietto F, Boffano P. Etiology and patternsof facial lacerations and their possible association with underlying maxillofacial fractures. J Craniofac Surg. 2011 Nov;22(6):e19-23. [Medline: 22134310] [doi: 10.1097/SCS.0b013e31822ec934]

26. Roccia F, Boffano P, Bianchi FA, Gerbino G. Maxillofacial injuries due to work-related accidents in the North West of Italy. Oral Maxillofac Surg. 2013 Sep;17(3):181-6. Epub 2012 Aug 7. [Medline: 22868983] [doi: 10.1007/s10006-012-0336-7] 
27. Roccia F, Boffano P, Bianchi FA, Ramieri G. An 11-year review of dental injuries associated with maxillofacial fractures in Turin, Italy. Oral Maxillofac Surg. 2013 Dec;17(4):269-74. Epub 2012 Nov 9. [Medline: 23138750] [doi: $10.1007 / \mathrm{s} 10006-012-0371-4$ ]

28. World Health Organization: WHO global report on falls prevention in older age. Chapter 1. 2007. p. 1. [URL: http://www.who.int/ageing/pubblications/Falls prevention7March.pdf]

29. Wang MY, Kim KA, Griffith PM, Summers S, McComb JG, Levy ML, Mahour GH. Injuries from falls in the pediatric population: an analysis of 729 cases. J Pediatr Surg. 2001 Oct;36(10):1528-34. [Medline: 11584402] [doi: 10.1053/jpsu.2001.27037]

30. Demetriades D, Murray J, Brown C, Velmahos G, Salim A, Alo K, Rhee P. High-level falls: type and severity of injuries and survival outcome according to age. J Trauma. 2005 Feb;58(2):342-5. [Medline: 15706198] [doi: 10.1097/01.TA.0000135161.44100.D8]

31. Kloss FR, Tuli T, Hächl O, Laimer K, Jank S, Stempfl K, Rasse M, Gassner R. The impact of ageing on craniomaxillofacial trauma-a comparative investigation. Int J Oral Maxillofac Surg. 2007 Dec;36(12):1158-63. Epub 2007 Sep 5. [Medline: 17822874] [doi: 10.1016/j.ijom.2007.07.009]

32. Roccia F, Bianchi F, Zavattero E, Tanteri G, Ramieri G. Characteristics of maxillofacial trauma in females: a retrospective analysis of 367 patients. J Craniomaxillofac Surg. 2010 Jun;38(4):314-9. Epub 2009 Nov 4. [Medline: 19892561] [doi: 10.1016/j.jcms.2009.10.002]

33. Clavijo-Alvarez JA, Deleyiannis FW, Peitzman AB, Zenati MS. Risk factors for death in elderly patients with facial fractures secondary to falls. J Craniofac Surg. 2012 Mar;23(2):494-8. [Medline: 22421856] [doi: 10.1097/SCS.0b013e31824cd383]

34. Fuller GF. Falls in the elderly. Am Fam Physician. 2000 Apr 1;61(7):2159-68, 2173-4. Review. [Medline: 10779256]

35. Nordell E, Jarnlo GB, Jetsén C, Nordström L, Thorngren KG. Accidental falls and related fractures in 65-74 year olds: a retrospective study of 332 patients. Acta Orthop Scand. 2000 Apr;71(2):175-9. [Medline: 10852324] [doi: 10.1080/000164700317413157]

36. McGwin G Jr, May AK, Melton SM, Reiff DA, Rue LW 3rd. Recurrent trauma in elderly patients. Arch Surg. 2001 Feb;136(2):197-203. [Medline: 11177141] [doi: 10.1001/archsurg.136.2.197]

37. Shaw FE. Falls in cognitive impairment and dementia. Clin Geriatr Med. 2002 May;18(2):159-73. [Medline: 12180241] [doi: $10.1016 /$ S0749-0690(02)00003-4]

38. Haug RH, Savage JD, Likavec MJ, Conforti PJ. A review of 100 closed head injuries associated with facial fractures. J Oral Maxillofac Surg. 1992 Mar;50(3):218-22. [Medline: 1542064] [doi: 10.1016/0278-2391(92)90315-Q]

39. Halazonetis JA. The 'weak' regions of the mandible. Br J Oral Surg. 1968 Jul;6(1):37-48. [Medline: 5244106] [doi: 10.1016/S0007-117X(68)80025-3]

40. Atanasijevic TC, Savic SN, Nikolic SD, Djoki VM. Frequency and severity of injuries in correlation with the height of fall. J Forensic Sci. 2005 May;50(3):608-12. [Medline: 15932094] [doi: 10.1520/JFS2004124]

41. Dickinson A, Roberts M, Kumar A, Weaver A, Lockey DJ. Falls from height: injury and mortality. J R Army Med Corps. 2012 Jun;158(2):123-7. [Medline: 22860503] [doi: 10.1136/jramc-158-02-11]

\section{To cite this article:}

Roccia F, Boffano P, Bianchi FA, Zavattero E. Maxillofacial Fractures due to Falls: does Fall Modality Determine the Pattern of Injury?

J Oral Maxillofac Res 2014;5(4):e5

URL: http://www.ejomr.org/JOMR/archives/2014/4/e5/v5n4e5ht.pdf

doi: $10.5037 /$ jomr.2014.5405

Copyright (C) Roccia F, Boffano P, Bianchi FA, Zavattero E. Published in the JOURNAL OF ORAL \& MAXILLOFACIAL RESEARCH (http://www.ejomr.org), 29 December 2014.

This is an open-access article, first published in the JOURNAL OF ORAL \& MAXILLOFACIAL RESEARCH, distributed under the terms of the Creative Commons Attribution-Noncommercial-No Derivative Works 3.0 Unported License, which permits unrestricted non-commercial use, distribution, and reproduction in any medium, provided the original work and is properly cited. The copyright, license information and link to the original publication on (http://www.ejomr.org) must be included. 